\title{
SCREENING OF DERIVATIVES OF 2-(BENZOYILAMINO) (1-R-2-OXOINDOLIN-3-YLIDENE)ACETIC ACID UNDER THE CONDITIONS OF ACUTE HYPOBARIC HYPOXIA
}

\author{
I.I.Zamorskii, Yu.S.Bukataru, E.L.Lenga, S.V.Kolisnyk, O.O.Altukhov \\ Higher State Educational Institution of Ukraine "Bukovinian State Medical University" \\ National University of Pharmacy
}

Key words: antihypoxants; hypobaric hypoxia; derivatives of 2-(benzoyilamino)(1-R-2-oxoindolin3-ylidene)acetic acid; mexidol

The results of screening of 2-(benzoyilamino)(1-R-2-oxoindolin-3-ylidene)acetic acid derivatives on the antihypoxic activity are presented in the article. It has been determined that under the conditions of acute hypobaric hypoxia compounds 4, 14 and 15 have shown the increase of the integral index of the antihypoxic activity of substances - the overall lifetime of animals at the "high-altitude plateau". However, the mortality rate of animals reached $20 \%$ for compound 4 , and it significantly exceeded the control data. At the same time, compound 14 by its antihypoxic activity significantly increased the overall lifetime of animals by $150 \%$ compared to the control data, but its effect was significantly weaker than the effect of the reference drug mexidol, which increased the lifetime of animals by $197 \%(p<0.05)$. For compound 15 the overall lifetime of animals increased by $186 \%$ compared to the control data $(p<0.05)$ and did not differ significantly from that of the reference drug. The data obtained indicate that most of the substances studied - derivatives of 2-(benzoyilamino)(1-R-2-oxoindolin-3-ylidene)acetic acid demonstrate certain antihypoxic properties, as well as derivatives of 2-(2-oxoindolin-3-ylidene)acetic acid previously researched. Moreover, only compound 15 corresponds to the antihypoxic efficacy of the reference drug, and by the index of recovery of the animals' physical activity after their staying at the "high-altitude plateau" (the posture recovery time) it exceeds the effect of the antihypoxant drug mexidol.

Hypoxia is a pathological condition that occurs when there is an insufficient supply of oxygen to tissues or disorder of oxygen uptake during the process of oxidation. It occurs under the conditions of oxygen deficiency in the environment, and as a result of various pathological processes and diseases associated with disorders of the respiratory and cardiovascular systems, the blood transport function or metabolism $[1,4]$. In addition, very high "hypoxic risk" is related to certain professions, such as pilots, astronauts, mountaineers, alpine tourists, divers and submariners, i.e. such working conditions that are associated with the low partial pressure of oxygen in the inhaled air. In everyday life people are influenced by the physiological hypoxia. Under the physiological conditions hypoxia develops during an intense muscular work, mental activity, significantly enhanced physiological activity of the liver, kidneys and gastrointestinal tract, fetal development and in old age. Consequently, practical medicine regularly faces the problem of protecting the body from complications arising from oxygen deficiency [9]. In this regard, drugs affecting the metabolism during hypoxia - antihypoxants, which are agents that improve oxygen consumption by the body and reduce oxygen demand of tissues and organs, thereby increasing the body's resistance to oxygen deficiency, are of particular interest. A wide choice of medicines with the antihypoxic activity is presented at the pharmaceutical market of Ukraine; mexidol is considered to be one of the most active and widely used drugs [3, 7], however, in many cases its action is not sufficiently effective. Thus, the search and introduction of new effective antihypoxants into clinical practice is a topical issue of medicine and pharmacy.

The aim of the current study was to conduct screening of the antihypoxic activity among 2-(benzoyilamino)(1-R-2-oxoindolin-3-ylidene)acetic acid derivatives under the conditions of acute hypobaric hypoxia.

\section{Materials and Methods}

24 Biologically active substances (BAS) - derivatives of 2-(benzoyilamino)(1-R-2-oxoindolin-3-ylidene)acetic acid - synthesized at the Department of Analytical Chemistry of the National University of Pharmacy by professor S.V.Kolisnyk were selected for study (Fig.).

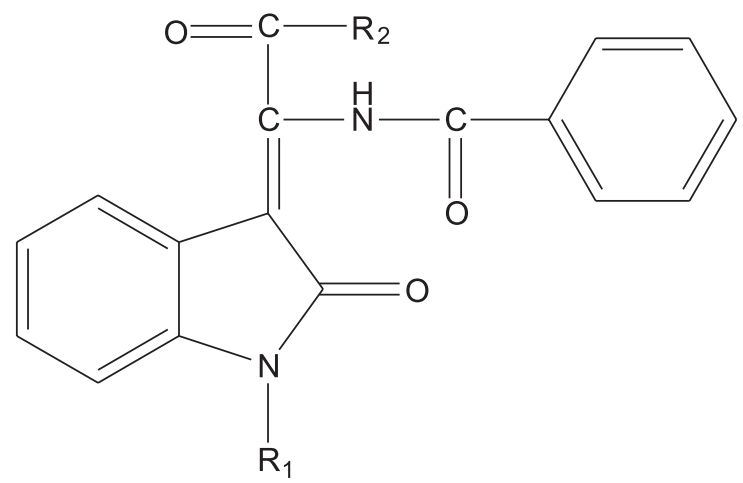

Fig. The structural formula of 2-(benzoyilamino)(1-R-2-oxoindolin-3ylidene)acetic acid derivatives (compounds 1-24). 
The life parameters of rats with acute hypobaric hypoxia of the critical level and when introducing

2-(benzoyilamino)(1-R-2-oxoindolin-3-ylidene)acetic acid derivatives and mexidol $(\mathrm{M} \pm \mathrm{m}, \mathrm{n}=6)$

\begin{tabular}{|l|c|c|c|}
\hline \multicolumn{1}{|c|}{ Group } & Time of the posture loss, s & $\begin{array}{c}\text { The lifetime till the second } \\
\text { agonal inspiration, s }\end{array}$ & $\begin{array}{c}\text { Time of the posture } \\
\text { recovery, s }\end{array}$ \\
\hline Control & $64.9 \pm 9.6$ & $15.3 \pm 8.3$ & $398.8 \pm 9.2$ \\
\hline Mexidol & $132.8 \pm 5.8^{*}$ & $25.6 \pm 8.6^{*}$ & $225.3 \pm 9.4^{*}$ \\
\hline Compound 1 & $66.7 \pm 4.7$ & $25.0 \pm 3.2^{*}$ & $244.7 \pm 5.8^{*}$ \\
\hline Compound 2 & $43.8 \pm 10.7$ & $15.0 \pm 2.5$ & $654.0 \pm 7.4^{*} / * *$ \\
\hline Compound 3 & $31.5 \pm 11.4$ & $19.7 \pm 11.8$ & $295.0 \pm 13.4^{*}$ \\
\hline Compound 4 & $131.3 \pm 18.7^{*}$ & $27.5 \pm 12.5$ & $363.2 \pm 14.4$ \\
\hline Compound 5 & $60.0 \pm 10.6$ & $14.0 \pm 5.2$ & $240.0 \pm 10.9^{*}$ \\
\hline Compound 6 & $57.5 \pm 7.8$ & $27.5 \pm 5.2$ & $263.6 \pm 6.9^{*}$ \\
\hline Compound 7 & $19.4 \pm 10.4^{*}$ & $9.6 \pm 7.2$ & $333.0 \pm 10.0$ \\
\hline Compound 8 & $23.0 \pm 5.9$ & $9.2 \pm 8.3$ & $257.3 \pm 4.2^{*}$ \\
\hline Compound 9 & $42.5 \pm 7.8$ & $51.3 \pm 3.9^{*} /^{* *}$ & $278.2 \pm 6.2^{*}$ \\
\hline Compound 10 & $23.0 \pm 10.5$ & $28.0 \pm 9.8$ & $215.2 \pm 10.0^{*}$ \\
\hline Compound 11 & $27.5 \pm 4.3$ & $12.8 \pm 5.8$ & $310.8 \pm 7.5^{*}$ \\
\hline Compound 12 & $39.0 \pm 10.3$ & $29.2 \pm 9.2$ & $205.2 \pm 8.8^{*}$ \\
\hline Compound 13 & $23.0 \pm 9.5$ & $14.0 \pm 10.3$ & $265.4 \pm 5.7^{*}$ \\
\hline Compound 14 & $69.5 \pm 8.2$ & $51.4 \pm 7.6^{*} / /^{* *}$ & $146.3 \pm 8.5^{*} / * *$ \\
\hline Compound 15 & $126.0 \pm 10.5^{*}$ & $23.5 \pm 5.7^{*}$ & $262.5 \pm 7.4^{*}$ \\
\hline Compound 16 & $13.4 \pm 8.4^{*}$ & $17.4 \pm 9.3$ & $312.8 \pm 4.2^{*}$ \\
\hline Compound 17 & $15.5 \pm 5.4^{*}$ & $9.8 \pm 3.8$ & $241.0 \pm 10.6^{*}$ \\
\hline Compound 18 & $61.0 \pm 6.7$ & $37.8 \pm 4.8^{*}$ & $308.0 \pm 10.7^{*}$ \\
\hline Compound 19 & $52.2 \pm 9.3$ & $24.4 \pm 7.3$ & $276.2 \pm 9.4^{*}$ \\
\hline Compound 20 & $25.2 \pm 4.8$ & $19.0 \pm 5.2$ & $289.8 \pm 9.7^{*}$ \\
\hline Compound 21 & $53.8 \pm 7.4$ & $17.4 \pm 6.4$ & $345.8 \pm 9.4$ \\
\hline Compound 22 & $19.8 \pm 3.9^{*}$ & $3.0 \pm 0.5^{*}$ & $341.4 \pm 8.7$ \\
\hline Compound 23 & $65.0 \pm 7.4$ & $42.0 \pm 4.6^{*}$ & $309.8 \pm 7.3^{*}$ \\
\hline Compound 24 & $70.0 \pm 6.5$ & $28.0 \pm 7.5$ & \\
\hline
\end{tabular}

Note: ${ }^{*}$ - significance compared to the control $(p<0.05) ;{ }^{* *}$ - significance compared to mexidol $(p<0.05)$.

2-(Benzoyilamino)(1-R-2-oxoindolin-3-ylidene) acetic acids (compounds 1-4), and their phenyl- (compounds 5-11), naphthalen- (compounds 12-14) phenethyl- (compounds 15-17), hydroxynaphthalenamides (compounds 23-24) and ethyl esters of $\mathrm{N}$-[2-(benzoyilamino) (2-oxoindolin3-ylidene)acetyl]glycine (compounds 18-22) were studied.

The animals were kept under the standard vivarium conditions at a constant temperature and humidity with free access to food and water. All manipulations were carried out in accordance with the European Union Directive 2010/63/EU on the protection of animals used for scientific purposes.

The research was conducted under the conditions of acute hypoxia on 156 nonlinear white mature male rats weighing 180-200 g aged 3 months and moderately resistant to hypoxia. The resistance of animals to hypoxia was determined 2 weeks prior to the research by the known method [2]. Acute hypobaric hypoxia was simulated in the modified flow pressure chamber by imitation of the lifting of rats to an altitude of 12000 metres. "Ascent" and "descent" of animals were carried out at a speed of $50 \mathrm{~m} / \mathrm{s}$. At the "high-altitude plateau" rats were main- tained until the second agonal inspiration, and then the "descent" to the previous zero altitude was performed [11]. The substances studied were administered intraperitoneally $35 \mathrm{~min}$ before hypoxia modelling in the dose of $15 \mathrm{mg} / \mathrm{kg}$ in the form of an aqueous suspension stabilized by polysorbate 80 (Tween 80) (AppliChem $\mathrm{GmbH}$, Germany) $[6,8]$. The reference drug - antihypoxant mexidol (ethylmethylhydroxypyridine succinate) was administered in the dose of $100 \mathrm{mg} / \mathrm{kg}$ [10]. The animals of the control group were injected with an equivalent amount of an aqueous suspension with polysorbate 80 . Doses of substances were selected according to the published data concerning the antihypoxic activity in experimental studies.

The antihypoxic activity of substances was assessed by the animals' survival indices at the "high-altitude plateau": the time of the posture loss; the lifetime - the time till the second agonal inspiration; the posture recovery time after termination of hypoxia and a gradual return of animals to the previous zero altitude; and the overall lifetime of animals - summation of the time of the posture loss and the lifetime [5]. 
Statistical analysis of the results was performed using SPSS Statistics 17.0 and Microsoft Excel 2013 software. Statistical significance was assessed using parametric Student's t-test (for normal distribution) and non-parametric Mann-Whitney U-test (in case of non-normal distribution). The critical level of significance was accepted as $\mathrm{p} \leq 0.05$.

\section{Results and Discussion}

The results of the antihypoxic activity screening of the compounds studied compared to the control group and the action of the reference drug mexidol are presented in Tab. 1.

Analysis of screening 2-(benzoyilamino)(1-R-2-oxoindolin-3-ylidene)acetic acid derivatives have shown that the most significant prolongation of life parameters in acute hypobaric hypoxia of the critical level according to the highest index of the lifetime at the "high-altitude plateau" after the loss of posture till the second agonal inspiration $(\mathrm{p}<0.05)$ have animals treated with compounds 1, 4, 9, 14, 15, 18, 23 and 24 (Tab. 1). The highest index of the time of the posture loss at the "high-altitude plateau" was for 2-(benzoyilamino)(1-propyl-2-oxoindolin-3-ylidene)acetic acid (compound 4) and for phenylethylamide 2-(benzoyilamino)(1-methyl-2-oxoindolin3 -ylidene)acetic acid (compound 15), it exceeded the control data by 2 and 1.9 times $(\mathrm{p}<0.05)$, respectively. The index of the posture recovery time after the beginning of the "descent" of animals from the "high-altitude plateau" was significantly lower compared to the control data for almost all BAS under research except compounds $\mathbf{2 , 4}$, $7,22,23$. In the group of phenylethylamide 15 this index was the lowest, and it significantly exceeded the antihypoxic efficacy of the reference drug mexidol by 1.5 times.

After administration of compounds 4, 9, 18, 23 and 24 such adverse reactions as convulsions and cyanosis of the skin and mucous membranes were observed. It was also found that among substances exhibiting the significant antihypoxic activity only compounds $\mathbf{1 4}$ and $\mathbf{1 5}$ did not cause any external signs of side effects after their administration when modelling hypoxia.

Compounds 4, 14 and 15 demonstrated the increase of the integral index of the antihypoxic activity of substances - the overall lifetime of animals at the "high-altitude plateau" (Tab. 2). However, the mortality rate of animals reached $20 \%$ for compound $\mathbf{4}$, and it significantly exceeded the control data. At the same time, amide 14 by its antihypoxic activity significantly increased the overall lifetime of animals by $150 \%$ compared to the cont-
The integral antihypoxic activity of some 2-(benzoyilamino)(1-R-2-oxoindolin-3-ylidene) acetic acid derivatives under the conditions of acute hypobaric hypoxia compared to the action of mexidol $(\mathrm{M} \pm \mathrm{m} ; \mathrm{n}=6)$

\begin{tabular}{|l|c|c|c|}
\hline \multicolumn{1}{|c|}{ Group } & $\begin{array}{c}\text { Overall } \\
\text { lifetime, } \mathrm{s}\end{array}$ & $\begin{array}{c}\text { Activity in } \\
\text { relation to } \\
\text { the control, } \\
\%\end{array}$ & $\begin{array}{c}\text { Activity in } \\
\text { relation to } \\
\text { mexidol, } \\
\%\end{array}$ \\
\hline Control & $80.2 \pm 17.9$ & & 100 \\
\hline Mexidol & $158.4 \pm 14.4^{*}$ & 197 & 100 \\
\hline Compound 4 & $158.8 \pm 31.2^{*}$ & 198 & 76 \\
\hline Compound 14 & $120.9 \pm 15.8^{*} /^{* *}$ & 150 & 94 \\
\hline Compound 15 & $149.5 \pm 16.2^{*}$ & 186 & \\
\hline
\end{tabular}

Note: * significance compared to the control $(p<0.05)$; ** - significance compared to mexidol $(p<0.05)$.

rol data, but its effect was significantly weaker than the effect of the reference drug mexidol, which increased the lifetime of animals by $197 \%(p \leq 0.05)$. For compound 15 the overall lifetime of animals increased by $186 \%$ compared to the control data $(\mathrm{p} \leq 0.05)$ and did not differ significantly from that of the reference drug.

The data obtained indicate that most of the substances studied - derivatives of 2-(benzoyilamino)(1-R-2-oxoindolin-3-ylidene)acetic acid - demonstrate certain antihypoxic properties, as well as derivatives of 2-(2-oxoindolin-3-ylidene)acetic acid previously researched [8]. Moreover, only compound $\mathbf{1 5}$ corresponds to the antihypoxic efficacy of the reference drug, and by the index of recovery of the animals' physical activity after their staying at the "high-altitude plateau" (the posture recovery time) it exceeds the effect of the antihypoxant drug mexidol.

\section{CONCLUSIONS}

1. The results of screening have shown that derivatives of 2-(benzoyilamino)(1-R-2-oxoindolin-3-ylidene) acetic acid are a promising class of compounds for creating antihypoxic medicines on their basis, and it is the basis for further pre-clinical studies of pharmacological properties of these compounds.

2. Compound $\mathbf{1 5}$ corresponds to the action of the reference drug mexidol by its antihypoxic activity, and significantly exceeds its effect by the index of recovery of the physical activity after the animals' staying at the "highaltitude plateau".

\section{REFERENCES}

1. Андреева Н.Н. // Мед. альманах. - 2009. - №4 (9). - С. 193-197.

2. Березовский В.А. Гипоксия и индивидуальные особенности реактивности. - К.: Наук. думка, 1978. - 216 c.

3. Воронина Т.А. // Журн. неврол. и психиатр. им. С.С.Корсакова. - 2012. - №12. - С. 86-90.

4. Евсеева М.А., Евсеев А.В., Правдивиев В.А. и др. // Обзоры по клин. фармакол. и лек. терапии. - 2008. T. 6, №1. - C. 3-25.

5. Заморський I.I. // Одеський мед. журн. - 1998. - №6 (50). - C. 23-25.

6. Зыкова С.С. // Вестник современ. клин. мед. - 2014. - T. 7, вып. 2. - С. 70-73. 
7. Катунина Н.П. // Наука и современность. - 2010. - №5. - С. 298-300.

8. Колісник С.В., Кононенко Н.М., Гаман Д.В. та ін. // Вісник фармаиї̈. - 2011. - №4 (68). - С. $64-66$.

9. Лукьянова Л.Д. // Фізіол. журн. - 2003. - Т. 49, №3. - С. 17-35.

10. Sevryukov O.V., Volkovoy V.A., Kolisnyk O.V. et al. // Biсник фармаuіï. - 2015. - №3 (83). - C. 76-78.

11. Zamorskii I.I., Sopova I.Yu., Khavinson V.Kh. // Bull. Exp. Biol. Med. - 2012. - Vol. 154, №1. - P. 51-53.

СКРИНІНГ ПОХІДНИХ 2-(БЕНЗОЇЛАМІНО)(1-R-2-ОКСОІНДОЛІН-3-ІЛІДЕН)ОЦТОВОЇ КИСЛОТИ ПРИ ГОСТРІЙ ГІПОБАРИЧНІЙ ГІПОКСІї

І.І.Заморський, Ю.С.Букатару, Е.Л.Ленга, С.В.Колісник, О.О.Алтухов

Ключові слова: антигіпоксанти; гіпобарична гіпоксія;

похідні 2-(бензоїламіно)(1-R-2-оксоіндолін-3-іліден)оцтової кислоти; мексидол

Наведені результати скринінгу похідних 2-(бензоїламіно)(1-R-2-оксоіндолін-3-іліден)оцтової кислоти на антигіпоксантну активність. Встановлено, що за умов гострої гіпобаричної гіпоксії збільшення інтегрального показника антигіпоксантної активності речовин - загальний час життя тварин на «висотному плато» - демонстрували речовини під номерами 4, 14 i 15. Проте для речовини 4 рівень смертності тварин при проведенні досліджень становив 20\%, що значно перевищувало контрольні дані. При цьому сполука під номером 14 за антигіпоксантною активністю достовірно збільшувала загальну тривалість життя тварин на $150 \%$ щодо даних контролю, але вірогідно поступалась препарату порівняння мексидолу: цей лікарський засіб збільшував час життя тварин на 197\% (p<0,05). Для речовини під номером 15 загальна тривалість життя тварин зростала на 186\% у порівнянні з даними контролю $(p<0,05)$ і вірогідно не відрізнялася від показників референс-препарату. Отримані дані вказують на те, що більшість досліджуваних речовин, похідних 2-(бензоїламіно)(1-R-2-оксоіндолін3-іліден)оцтової кислоти проявляють певні антигіпоксантні властивості. Водночас тільки речовина за номером 15 не поступається за антигіпоксантною ефективністю дії препарату порівняння, а за показником відновлення фрізичної активності тварин після їх перебування на «висотному плато» (часом відновлення пози) перевершує дію відомого антигіпоксанта мексидолу.

\section{СКРИНИНГ ПРОИЗВОДНЫХ 2-(БЕНЗОИЛАМИНО)(1-R-2-ОКСОИНДОЛИН-3-ИЛИДЕН)}

\section{УКСУСНОЙ КИСЛОТЫ ПРИ ОСТРОЙ ГИПОБАРИЧЕСКОЙ ГИПОКСИИ}

\section{И.И.Заморский, Ю.С.Букатару, Э.Л.Ленга, С.В.Колесник, А.А.Алтухов}

Ключевые слова: антигипоксанты; гипобарическая гипоксия; производные

2-(бензоиламино)(1-R-2-оксоиндолин-3-илиден)уксусной кислоты; мексидол

Приведены результаты скрининга производных 2-(бензоиламино)(1-R-2-оксоиндолин-3-илиден) уксусной кислоты на антигипоксантную активность. Установлено, что в условиях острой гипобарической гипоксии увеличение интегрального показателя антигипоксантной активности веществ - общее время жизни животных на «высотном плато» - демонстрировали вещества под номерами 4, 14 и 15. Однако, для вещества 4 уровень смертности животных при проведении исследований составил $20 \%$, что значительно превышало контрольные данные. При этом соединение под номером 14 по антигипоксантной активности достоверно увеличивало общую продолжительность жизни животных на 150\% относительно данных контроля, но достоверно уступало препарату сравнения мексидолу: это лекарственное средство увеличивало время жизни животных на 197\% (p<0,05). Для вещества под номером 15 общая продолжительность жизни животных возрастала на 186\% по сравнению с данными контроля $(p<0,05)$ и достоверно не отличалась от показателей ресреренс-препарата. Полученные данные указывают на то, что большинство исследуемых веществ, производных 2-(бензоиламино)(1-R-2-оксоиндолин-3-илиден)уксусной кислоты проявляют определенные антигипоксантные свойства. В то же время только вещество под номером 15 не уступает по антигипоксантной эфффективности действию препарата сравнения, а по показателю восстановления фризической активности животных после их пребывания на «высотном плато» (время восстановления позы) превосходит действие известного антигипоксанта мексидола. 